\title{
PENGEMBANGAN MEDIA PEMBELAJARAN DREAMWEAVER MODEL TUTORIAL PADA MATA PELAJARAN MENGELOLA ISI HALAMAN WEB UNTUK SISWA KELAS XI PROGRAM KEAHLIAN MULTIMEDIA DI SMK NEGERI 3 SINGARAJA
}

Oleh

\author{
Gd Tuning Somara Putra', Made Windu Antara Kesiman, S.T., M.Sc., \\ I Gede Mahendra Darmawiguna,S.Kom.,M.Sc \\ Jurusan Pendidikan Teknik Informatika, Fakultas Teknik dan \\ Kejuruan,Universitas Pendidikan Ganesha (Undiksha) \\ e-mail: tnttunink@yahoo.co.id ${ }^{1}$
}

\begin{abstract}
ABSTRAK
Pengembangan media pembelajaran model tutorial ini bertujuan untuk, 1) merancang media pembelajaran dreamweaver model tutorial pada mata pelajaran mengelola isi halaman web untuk siswa kelas XI program keahlian multimedia di SMK Negeri 3 Singaraja, 2) mengimplementasikan media pembelajaran dreamweaver model tutorial pada mata pelajaran mengelola isi halaman web untuk siswa kelas XI program keahlian multimedia di SMK Negeri 3 Singaraja, 3) mengetahui respon siswa dan guru, di kelas XI multimedia SMK Negeri 3 Singaraja terhadap pengembangan media pembelajaran dreamweaver model tutorial pada mata pelajaran mengelola isi halaman web.

Berdasarkan pemaparan di atas, maka dipandang perlu untuk mengembangkan sebuah media pembelajaran dreamweaver model tutorial pada mata pelajaran mengelola isi halaman web untuk siswa kelas XI program keahlian multimedia di SMK Negeri 3 Singaraja. Pengembangan media ini menggunakan model waterfall. Perangkat lunak yang digunakan untuk pengembangan media ini yaitu Macromedia Flash 8 serta beberapa software pendukung seperti Photoshop untuk membuat dan mengedit gambar, Cool Edit Pro 2 untuk pengolahan suara, dan Adobe Premiere Pro1.5, Camtasia Studio 7 untuk editing video, Adobe Dreamweaver Cs3, Macromedia Dreamweaver, Xampp sebagai software uji dalam media ini.

Media pembelajaran dreamweaver model tutorial memiliki fungsi yang berbeda pada setiap menunya. Seperti menu materi yang berisikan materi pelajaran, video tutorial yang memiliki video, sebagai alat bantu ajar dan evaluasi sebagai alat uji kemampuan siswa. Dari uji coba media pembelajaran dreamweaver kepada siswa hasil penelitian menunjukan bawha respon siswa tersebar pada kategori sangat positif $2,77 \%$, positif 97,23. Sedangkan untuk respon guru tersebar pada kategori sangat positif $100 \%$. Respon siswa dan respon guru, tersebar pada kategori positif.
\end{abstract}

Kata-kata kunci: media pembelajaran, model tutorial, dreamweaver. 


\section{PENDAhuluan}

Pendayagunaan IPTEK (ilmu pengetahauan dan teknologi), sebagai sarana pendukung pembelajaran merupakan salah satu dampak positif dari kemajuan teknologi. Perkembangan teknologi informasi, merupakan salah satu kemajuan teknologi yang bisa diterapkan dan dijadikan acuan dalam mengembangkan pengetahuan. TIK (teknologi informasi) berkembang dan menjadi bagian yang tidak dapat dipisahkan dari kehidupan manusia, peran teknologi informasi sudah merambah ke segala bidang kehidupan, terlebih lagi dalam bidang pendidikan. Media pembelajaran interaktif merupakan salah satu produk berbasis TIK yang dimanfaatkan untuk memudahkan dan membangkitkan minat belajar siswa. Produk-produk TIK dalam kegiatan intra-kurikuler, oleh Laurahasiel (2009) sering disebut sebagai salah satu bentuk media pembelajaran. Media pembelajaran merupakan salah satu komponen dalam kegiatan belajar mengajar, yang biasanya dibuat oleh guru/pendidik/pengajar. Fungsi media pembelajaran adalah sebagai pembawa informasi dari sumber (guru) menuju penerima (siswa) (Santyasa, 2007).

SMK Negeri 3 Singaraja merupakan salah satu sekolah kejuruan yang telah menerapkan kurikulum KTSP (Kurikulum Tingkat Satuan Pendidikan) dalam kegiatan pembelajaran. KTSP adalah kurikulum operasional yang disusun dan dilaksanakan di masing-masing satuan pendidikan. KTSP mengutamakan active learning, yakni hubungan dua arah antara guru dengan peserta didik, student centered (peserta didik sebagai pusat pembelajaran) (Depdiknas, 2007). Salah satu jurusan di SMK N 3 Singaraja yang menerapkan KTSP dalam pembelajaran adalah jurusan Multimedia, jurusan multimedia merupakan salah satu jurusan yang memiliki mata pelajaran sangat inovatif, karena lebih mengedepankan teknologi informasi sebagai dasar penunjang pembelajaran, untuk mengedepankan proses pembelajaran multimedia, harus didukung oleh media pembelajaran yang interaktif, dan disesuaikan dengan kondisi peserta didik.

Berdasarkan hasil observasi dan wawancara penulis dengan guru dan beberapa orang siswa di SMK Negeri 3 Singaraja, menemukan beberapa permasalahan dalam pembelajaran multimedia khususnya dalam bidang studi mengelola halaman web, antara lain:, 1) kurangnya minat siswa dalam mempelajari web, karena dirasa sangat rumit dan sukar, dikarenakan siswa kurang mampu menyimak pembelajaran dengan baik, 2) guru kurang memancing siswa untuk bertanya, akibatnya siswa takut bertanya dan tidak berani mengemukakan pendapat karena takut salah dengan apa yang disampaikan, 3) jumlah siswa terlalu banyak dalam satu kelas mencapai 30 orang, 4) siswa kurang aktif dalam kegiatan pembelajaran baik bertanya maupun menjawab, siswa hanya diam dan menerima begitu saja penjelasan dari guru.

Haryoko (2009 : 2) dalam jurnal Efektivitas Pemanfaatan Media AudioVisual Sebagai Alternatif Optimalisasi Model Pembelajaran menyebutkan penyampaian materi atau bahan ajar melalui media adio-visual dapat memungkinkan mahasiswa melakukan eksplorasi lebih dalam. Pengembangan media pembelajaran model tutorial merupakan langkah signifikan untuk dikembangkan menjadi alat bantu ajar di SMK N 3 Singaraja, karena model 
tutorial bertujuan untuk menyampaikan atau menjelaskan materi tertentu dimana komputer menyampaikan materi, mengajukan pertanyaan dan memberikan umpan balik sesuai dengan jawaban siswa. Dalam menyajikan materi, tutorial dapat dibedakan menjadi tutorial linier dan tutorial bercabang. Tutorial linier menyajikan suatu topik ke topik berikutnya sesuai urutan yang telah ditetapkan oleh pemrogram, sehingga siswa tidak dapat memilih materi pembelajaran sesuai keinginan dan kemampuannya. Tutorial bercabang perbedaan individu diperhatikan dengan memberikan kebebasan pada siswa untuk mempelajari materi sesuai keinginan dan kemampuannya.

Penyajian materi dan topik pada tutorial bercabang menyesuaikan dengan pilihan dan kemampuan siswa. Definisi tutorial dalam pembelajaran berbasis komputer sebagaimana diungkapkan Hernawan (2004) dan Rusman (2008) adalah pembelajaran khusus dengan instruktur yang terkualifikasi dengan menggunakan software komputer yang berisi materi pelajaran yang bertujuan untuk memberikan pemahaman secara tuntas (mastery learning) kepada siswa mengenai bahan atau materi pelajaran yang sedang dipelajari. Menurut (Udayana : 2010) dalam jurnal Pengembangan Media Pembelajaran Multimedia Model Tutorial Pada Mata Pelajaran Animasi 3 Dimensi, Penggunaan media pembelajaran model tutorial dalam proses belajar mengajar dapat meningkatkan efisiensi, meningkatkan motivasi, memfasilitasi belajar aktif, memfasilitasi belajar eksperimental, konsisten dengan belajar yang berpusat pada siswa dan memandu untuk belajar lebih baik. Selain itu dalam pengembangan media pembelajaran model tutorial ini, diterapkan proses drill And practice (latihan dan praktik), dimana dalam proses ini ditekankan pada siswa yang telah mempelajari konsep dengan tujuan untuk memantapkan konsep yang telah dipelajari.

Pembelajarann Mengelola isi halaman web adalah salah satu mata pelajaran yang harus diselesaikan oleh siswa yang mengambil bidang keahlian multimedia di SMK N 3 Singaraja. Pembelajaran Mengelola isi halaman web ini, dikhususkan pada pengoperasian software dreaweaver. Dreamweaver merupakan salah satu software pembuat website yang mempunyai banyak sekali kemudahan dalam pengoperasiannya dan sangat powerful dalam pembuatan website. Salah satu keunggulannya adalah kemudahannya dalam berinteraksi dengan macromedia flash, sebuah tool animasi yang sangat populer di internet. Dalam pengoperasian software dreamweaver, siswa dapat membuat dan mengelola isi halaman web sehingga pembelajaran ini tercapai. Media pembelajaran sangat mendukung siswa untuk dapat aktif dalam belajar, karena media pembelajaran dilengkapi dengan alat pengontrol yang dapat dioperasikan oleh pengguna, sehingga pengguna dapat memilih apa yang dikehendaki untuk proses selanjutnya ataupun dapat berinteraksi dengan media.

Media ini menggabungkan dan mensinergikan semua media yang terdiri dari teks, grafis, foto, video, animasi, musik, narasi, dan interaktivitas yang diprogram berdasarkan teori pembelajaran. Kegiatan belajar melalui pengembangan media pembelajaran model tutorial memungkinkan siswa dapat mengembangkan kemampuan berfikir, membangun konsep, keterampilan dan kreativitas. Hal ini relevan dengan prinsip-prinsip transformasi teknologi informasi dan komunikasi dalam diri siswa yang seyogyanya dilakukan dalam interaksi berdasarkan prinsip: (1) penghargaan terhadap perkembangan 
multimedia, (2) identifikasi diri terhadap implikasi multimedia, (3) pengetahuan yang terkonsep, (4) meningkatkan keterampilan dan kreativitas.

Bertitik tolak pada pemaparan diatas, maka peneliti tertarik untuk meneliti terkait "Pengembangan Media Pembelajaran Dreamweaver Model Tutorial pada Mata Pelajaran Mengelola Isi Halaman Web untuk Siswa Kelas XI Program Keahlian Multimedia di SMK Negeri 3 Singaraja".

\section{KAJIAN PUSTAKA}

\subsection{PENGEMBANGAN}

Menurut Soenarto (2005) mengartikan pengembangan sebagai suatu proses untuk mengembangkan dan memvalidasi produk-produk yang akan digunakan dalam pendidikan dan pembelajaran. Penelitian pengembangan adalah upaya untuk mengembangkan dan menghasilkan suatu produk berupa materi, media, alat, dan strategi pembelajaran yang dapat digunakan untuk mengatasi masalah pembelajaran di kelas/ laboratorium, dan bukan untuk menguji teori. Pengembangan atau sering disebut juga sebagai penelitian pengembangan, dilakukan untuk menjembatani antara penelitian pendidikan (Ardhana, 2002). Hasil dari penelitian pengembangan adalah berupa produk, dalam hal ini adalah media pembelajaran, perangkat lunak (software) yaitu isi dari media pembelajaran tersebut, sedangkan perangkat keras (hardware) adalah berupa alat yang dijadikan tempat dari isi media tersebut yang dapat berupa CD (Compact Disc) maupun yang lainnya.

\subsection{MODEL TUTORIAL}

Berdasarkan asal kata, tutorial dapat diartikan dalam dua kategori bentuk kata, yaitu kata benda dan kata kerja. Sebagai kata benda tutorial berarti pelajaran pribadi, guru pribadi, pengajaran tambahan sedangkan sebagai kata kerja tutorial berarti mengajar di rumah, mengajar ekstra, memberi les, pengajaran tambahan, pengajaran pribadi.

Sedangkan tutorial secara istilah adalah bimbingan pembelajaran dalam bentuk pemberian bimbingan, bantuan, petunjuk, arahan dan motivasi agar siswa belajar secara efektif dan efisien (Hamalik, 2005). Pemberian bimbingan berarti membantu para siswa memecahkan masalah-masalah belajar. Pemberian bantuan berarti membantu siswa dalam mempelajari program. Pemberian petunjuk berarti memberikan cara belajar agar siswa lebih belajar secara efektif dan efisien. Pemberian arahan berarti mengarahkan para siswa untuk mencapai tujuan pembelajaran yang ditetapkan dan pemberian motivasi berarti memberikan semangat untuk lebih mengikuti pembelajaran yang diterapkan.

Definisi tutorial dalam pembelajaran berbasis komputer sebagaimana diungkapkan Hernawan (2004) dan Rusman (2008) adalah pembelajaran khusus dengan instruktur yang terkualifikasi dengan menggunakan software komputer yang berisi materi pelajaran yang bertujuan untuk memberikan pemahaman secara tuntas (mastery learning) kepada siswa mengenai bahan atau materi pelajaran yang sedang dipelajari. 
Dalam tutorial, komputer berperan sebagai guru sehingga semua interaksi terjadi antara komputer dengan peserta didik sedangkan guru hanya sebagai fasilitator dan pemantau. Dalam model ini, sebenarnya software program komputer menggantikan sistem tutor yang dilakukan oleh guru atau instruktur. Pembelajaran dalam model ini disajikan melalui teks atau grafik yang ditampilkan oleh layar komputer. Kemudian komputer menampilkan pertanyaan sesuai dengan masalah yang disajikan. Secara sederhana pola-pola pengoperasian dalam pembelajaran berbasis komputer model tutorial dapat dilihat sebagai berikut:
a. Komputer menyajikan materi
b. Siswa memberikan respon
c. Respon siswa dievaluasi oleh komputer dengan orientasi siswa pada arah siswa dalam menempuh presentasi berikutnya.
d. Melanjutkan atau mengulangi tahapan sebelumnya.

Model berbasis komputer tipe tutorial ini memiliki 2 jenis:

\section{Tutorial Terprogram}

Tutorial terprogram merupakan seperangkat tayangan baik statis maupun dinamis yang terlebih dahulu diprogramkan. Secara berturut, seperangkat kecil informasi ditayangkan yang diikuti dengan pertanyaan. Jawaban siswa dianalisis oleh komputer (dibandingkan dengan kemungkinan-kemungkian jawaban yang telah dirancang oleh si pembuat program/guru), dan berdasarkan hasil analisis itu umpan balik yang sesuai. Urutan linear dan urutan bercabang digunakan. Penetapan kapan bercabang dimaksudkan untuk penyajian materi pelajaran tambahan berdasarkan hasil analisis perkembangan siswa setelah menyelesaikan beberapa latihan dan tugas. Semakin banyak alternatif cabang yang tersedia, semakin luwes program tersebut menyesuaikan diri dengan perbedaan individual siswa. Media tambahan lain biasanya digabungkan untuk format tutorial terprogram, seperti tugas tugas bacaan berbasis cetak, kegiatan kelompok, percobaan laboratorium, kegiatan latihan, simulasi dan interaktif dengan videodisk. Manfaat tutorial terprogram akan nampak jika menggunakan kemampuan teknologi komputer untuk bercabang dan interaktif.

\section{Tutorial Intelijen}

Berbeda dari tutorial terprogram karena jawaban komputer terhadap pertanyaan siswa dihasilkan oleh intelegensia artifisial (kecerdasan buatan), bukan jawaban-jawaban yang terprogram yang telah disiapkan terlebih dahulu oleh si perancang. Dengan demikian, ada dialog dari waktu ke waktu antara siswa dengan komputer. Baik siswa maupun komputer dapat bertanya ataupun memberi jawaban. 
Terdapat 8 identitas model Tutorial dalam pembelajaran berbasis komputer, yaitu:

1. Pengenalan (introduction)

2. Penyajian informasi (presentation of information)

3. Pertanyaan dan respon (question and responses)

4. Penilaian respon (judging responses)

5. Pemberian feedback terhadap respon (providing feedback about responses)

6. Pembetulan/Pengulangan (remediation)

7. Segmen pengaturan pengajaran (sequencing lesson segment)

8. Penutup (Closing)

\subsection{MEDIA PEMBELAJARAN}

Proses belajar mengajar akan berjalan efektif dan efisien bila didukung dengan tersedianya media yang menunjang. Penyediaan media serta metodologi pendidikan yang dinamis, kondusif serta dialogis sangat diperlukan bagi pengembangan potensi peserta didik, secara optimal. Hal ini disebabkan karena potensi peserta didik akan lebih terangsang bila dibantu dengan sejumlah media atau sarana dan prasarana yang mendukung proses interaksi yang sedang dilaksanakan. Media dalam perspektif pendidikan merupakan instrumen yang sangat strategis dalam ikut menentukan keberhasilan proses belajar mengajar. Sebab keberadaannya secara langsung dapat memberikan dinamika tersendiri terhadap peserta didik.

\subsubsection{Pengertian Media Pembelajaran}

Kata media berasal dari bahasa latin dan merupakan bentuk jamak dari kata medium yang secara harfiah berarti perantara atau pengantar. Banyak batasan yang diberikan orang tentang media. Asosiasi Teknologi dan komunikasi pendidikan (Association of Education and Comunication Technology/ AECT) di Amerika, membatasi media sebagai segala bentuk dan saluran yang digunakan orang untuk menyalurkan pesan/ Informasi.

Media adalah sebuah alat yang mempunyai fungsi menyampaikan pesan (Bovee, 1997). Media pembelajaran adalah sebuah alat yang berfungsi untuk menyampaikan pesan pembelajaran. Pembelajaran adalah sebuah proses komunikasi antara pembelajar, pengajar dan bahan ajar. Komunikasi tidak akan berjalan tanpa bantuan sarana penyampai pesan atau media. Bentuk-bentuk stimulus bisa dipergunakan sebagai media diantaranya adalah hubungan atau interaksi manusia, gambar bergerak atau tidak, tulisan dan suara yang direkam.

\subsection{MENGELOLA ISI HALAMAN WEB}

Salah satu materi yang diajarkan pada mata pelajaran Teknologi Informasi dan Komunikasi jurusan multimedia di SMK Negeri 3 Singaraja adalah mata 
pelajaran mengelola isi halaman web. Mengelola isi halaman web adalah mata pelajaran yang menuntut siswa untuk mengaplikasikan software dreamweaver sebagai pendukung dalam pembelajaran. Dreamweaver merupakan salah satu software pembuat website yang mempunyai banyak sekali kemudahan dalam pengoperasiannya dan sangat powerful dalam pembuatan website. Salah satu keunggulannya adalah kemudahannya dalam berinteraksi dengan macromedia flash, sebuah tool animasi yang sangat populer di internet.

\subsection{KEUNGGULAN DREAMWEAVER}

\subsubsection{Kemampuannya membuat halaman web yang terlihat konsisten}

2.5.2 Kemudahan dan efisiensi dalam penggunaan

Dreamwaver memiliki kemampuan memperlihatkan 3 proses yang berbeda, yaitu :

1) Code View : Berfungsi untuk hanya menampilkan script html saja.

2) Desain View : Berfungsi menampilkan kode-kode html yang anda tulis menjadi sebuah design/template yang nantinya akan ditampilkan di browser.

3) Split View : Berfungsi menampilkan gabungan antara Code View dan Desain View pada saat bersamaan.Jadi anda bisalangsung melihat perubahan pada saat anda mengubah htmlnya.

\subsubsection{Dapat dikustom}

Dreamweaver dapat disesuaikan dengan kebutuhan yang anda perlukan. Menu, tab, perintah, font dan warna semua kode dapat disesuaikan dengan preferensi pribadi. Hal ini dapat secara efektif memudahkan proses desain web. Selain itu dreamweaver didukung banyak plug-in yang membantu anda dalam proses desain.

\section{METODOLOGI PENELITIAN}

\subsection{MODEL PENELITIAN}

Jenis penelitian yang dilaksanakan adalah Penelitian dan Pengembangan (Research and Development $/ R \& D$ ). Penelitian dan Pengembangan adalah metode penelitian yang digunakan untuk menghasilkan produk tertentu atau mengembangkan produk yang telah ada serta menguji keefektifan produk tersebut. Produk tersebut tidak selalu berbentuk benda atau perangkat keras (hardware), seperti buku, modul, alat bantu pembelajaran di kelas atau di laboratorium, tetapi bisa juga perangkat lunak (software), seperti program komputer untuk pengolahan data, pembelajaran di kelas, perpustakaan atau 
laboratorium, ataupun model-model pendidikan, pembelajaran, pelatihan, bimbingan, evaluasi, sistem manajemen, dan lain-lain (Sugiyono, 2008).

\subsection{MODEL PENGEMBANGAN}

Model pengembangan yang digunakan yaitu model pengembangan Dick and Carey. Langkah pada model Dick and Carey menunjukan hubungan yang sangat jelas, dan tidak terputus antara langkah yang satu dengan yang lainya. Dengan kata lain, sistem yang terdapat pada Dick and Carey sangat ringkas, namun isinya padat dan jelas dari satu urutan ke urutan berikutnya. 
ISSN 2089-8673

Jurnal Nasional Pendidikan Teknik Informatika (JANAPATI)

Volume 1, Nomor 2, Juli 2013

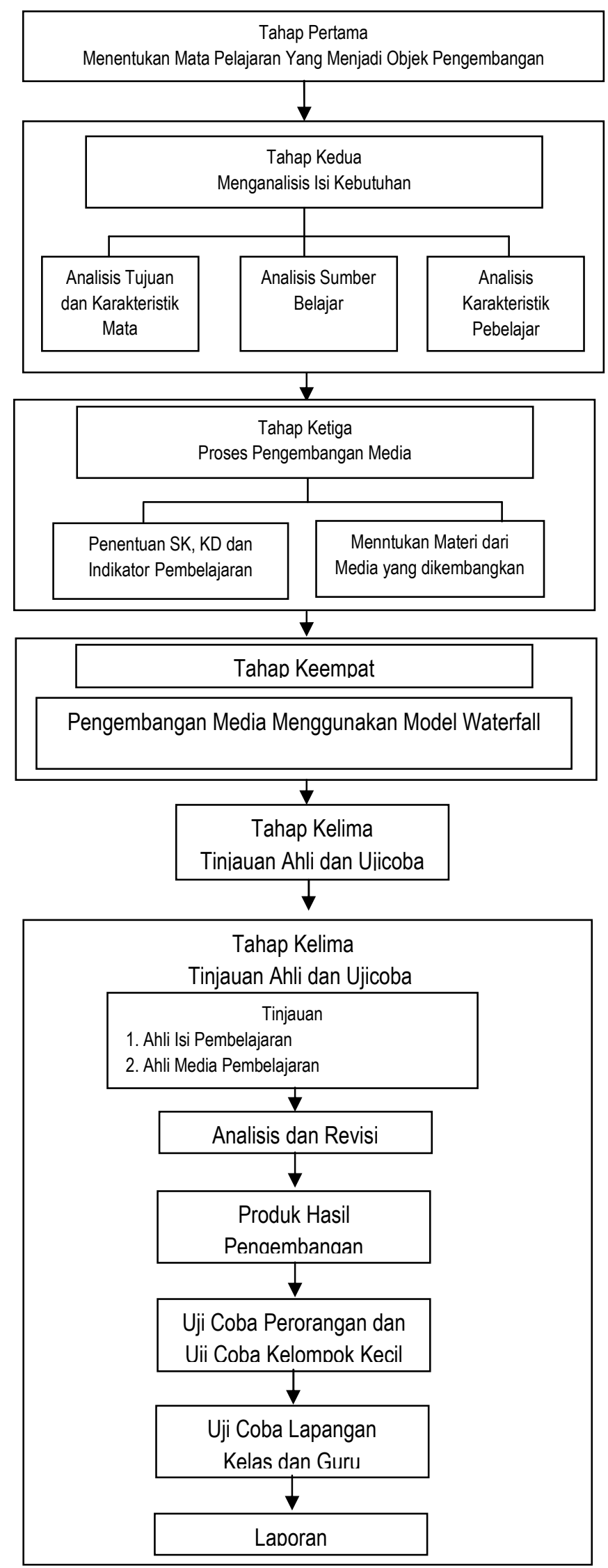

Gambar 3.1 Desain Pengembangan 
Dari bagan di atas dapat dilihat tahapan-tahapan pengembangan pembelajaran sebagai berikut.

1. Menetapkan mata pelajaran yang akan dikembangkan, pengembangan media pembelajaran model tutorial ini dimulai dengan menentukan mata pelajaran sebagai objek pengembangan.

2. Tahap kedua, yaitu menganalisis segala sesuatu yang dibutuhkan dalam pengembangan

3. Tahap ketiga, yaitu tahap proses pengembangan media. Pada tahap ini menentukan Indikator yang dirumuskan yang terdapat pada Silabus. Materi yang dibuat pada media ini berdasarkan jumlah kompetensi dasar yang ada yaitu (1) Memeriksa informasi untuk relevansi dan updated (2) Memeriksa links dan navigasi, (3) Mengedit informasi sesuai kebutuhan, dan (4) Menguji dan memastikan perubahan-perubahan. Silabus terlampir (Lampiran 10).

4. Tahap keempat, yaitu tahap pengembangan media pembelajaran model tutorial. Tahap pengembangan media ini menggunakan model waterfall.

5. Tahap kelima, yaitu tinjauan ahli dan uji coba terhadap produk. Pada tahap ini yang melakukan validasi atau tinjauan dari ahli isi atau materi, ahli media dan ahli disain yang bertujuan untuk mengetahui kelayakan dari produk yang dikembangkan. Apabila dalam tahap ini ada perbaikan terhadap media yang dikembangkan, maka masuk pada tahap revisi.

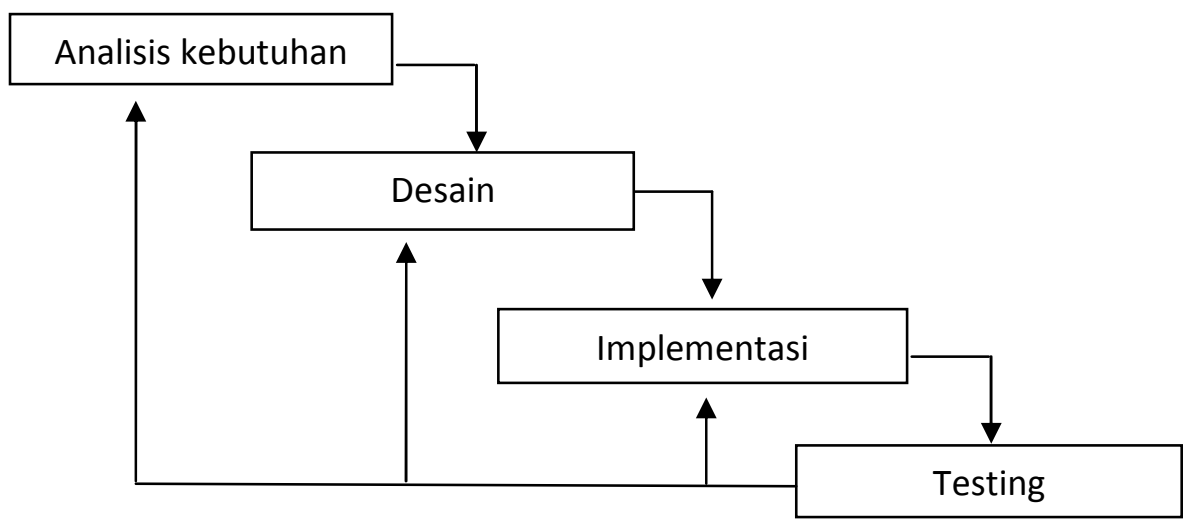

Gambar 3.2 Desain Model Waterfall diadopsi dari Somerville dalam

Rahmawati Noor Fajar, 2010 dengan perubahan penulis)

\subsection{TEKNIK ANALISIS DATA}

Dalam penelitian pengembangan ini digunakan dua teknik analisis data, teknik analisis deskrptif kualitatif dan analisis statistik deskriptif.

\section{(1) Analisis Deskriptif Kualitatif}

Teknik analisis deskriptif kualitatif ini digunakan untuk mengolah data hasil review ahli isi bidang studi atau mata pelajarn, ahli media, ahli desain media, dan siswa dari hasil uji coba perorangan, kelompok kecil, dan lapangan. 
(2) Analisis Statistik Deskriptif

Analisis ini didasarkan pada rata-rata kelas $(\bar{R})$ dari respon siswa, Mi, dan Sdi. Nilai rata-rata respon siswa $(\bar{R})$ dapat dihitung dengan menggunakan rumus sebagai berikut.

$$
\bar{R}=\frac{\sum R}{N}
$$

Keterangan:

$\bar{R} \quad=$ Skor rata-rata respon siswa.

$\sum R=$ Jumlah skor respon belajar siswa

$N \quad=$ Banyaknya siswa

Untuk mencari mean ideal (MI) dan standar deviasi ideal (SDI) dapat dilakukan dengan menggunakan rumus berikut.

$$
\begin{aligned}
& \text { MI }=\frac{1}{2}(\text { skor tertinggi ideal }+ \text { skor terendah ideal }) \\
& \text { SDI }=\frac{1}{6}(\text { skor tertinggi ideal }+ \text { skor terendah ideal })
\end{aligned}
$$

Rata-rata kelas $(\bar{R})$ dari skor respon siswa kemudian dikategorikan dengan menggunakan pedoman seperti pada tabel berikut.

Tabel 3.1 Kriteria penggolongan respon siswa (diadaptasi dari Candiasa, 2010:41)

\begin{tabular}{|r|l|c|}
\hline No & \multicolumn{1}{|c|}{ Interval } & Kategori \\
\hline 1 & $\bar{R} \geq \mathrm{MI}+1,8 \mathrm{SDI}$ & Sangat positif \\
\hline 2 & $\mathrm{MI}+1,8 \mathrm{SDI}>\bar{R} \geq \mathrm{MI}+0,6 \mathrm{SDI}$ & Positif \\
\hline 3 & $\mathrm{MI}+0,6 \mathrm{SDI}>\bar{R} \geq \mathrm{MI}-0,6 \mathrm{SDI}$ & Cukup \\
\hline 4 & $\mathrm{MI}-0,6 \mathrm{SDI}>\bar{R} \geq \mathrm{MI}-1,8 \mathrm{SDI}$ & Kurang positif \\
\hline 5 & $\bar{R}<\mathrm{MI}-1,8 \mathrm{SDI}$ & Sangat kurang positif \\
\hline
\end{tabular}

\section{HASIL DAN PEMBAHASAN}

\subsection{HASIL PENGEMBANGAN MEDIA PEMBELAJARAN DREAMWEAVER MODEL TUTORIAL}

\subsubsection{Menetapkan mata pelajaran yang akan dikembangkan}

Pengembangan media pembelajaran dreamweaver model tutorial dimulai dengan menentukan mata pelajaran sebagai objek pengembangan. mata pelajaran yang diambil adalah mengelola isi halaman web karena pada mata pelajaran ini, 
siswa yang mengambil program keahlian multimedia belum menggunakan media pembelajaran dreamweaver model tutorial dan mandiri selama proses pembelajaran ditambah lagi kesulitan guru dalam mengilustrasikan materi yang diajarkan.

\subsubsection{Mendesain Produk}

\subsubsection{Rancangan Sistem}

Rancangan sistem dari media pembelajaran model tutorial pada mata pelajaran mengelola isi halaman web, dapat digambarkan dengan menggunakan Data Flow Diagram (DFD).

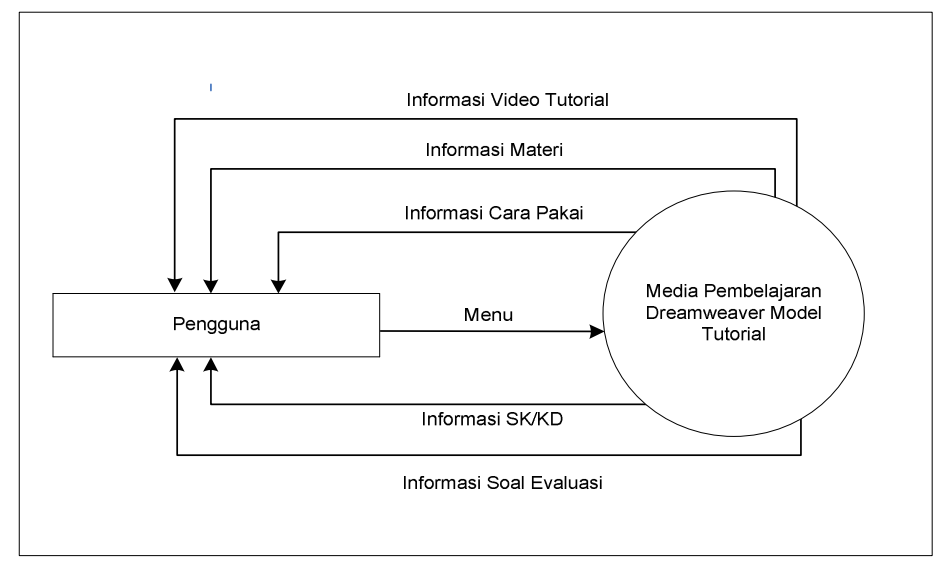

Gambar 4.1 Diagram konteks Media Pembelajaran Dreamweaver Model Tutorial Pada Mata Pelajaran Mengelola Isi Halaman Web

\subsubsection{Rancangan Antarmuka}

Rancangan antarmuka merupakan rancangan awal dari pembuatan formform yang ada pada media pembelajaran multimedia model tutorial pada mata pelajaran mengelola isi halaman web. Rancangan antarmuka media pembelajaran ini adalah sebagai berikut. 


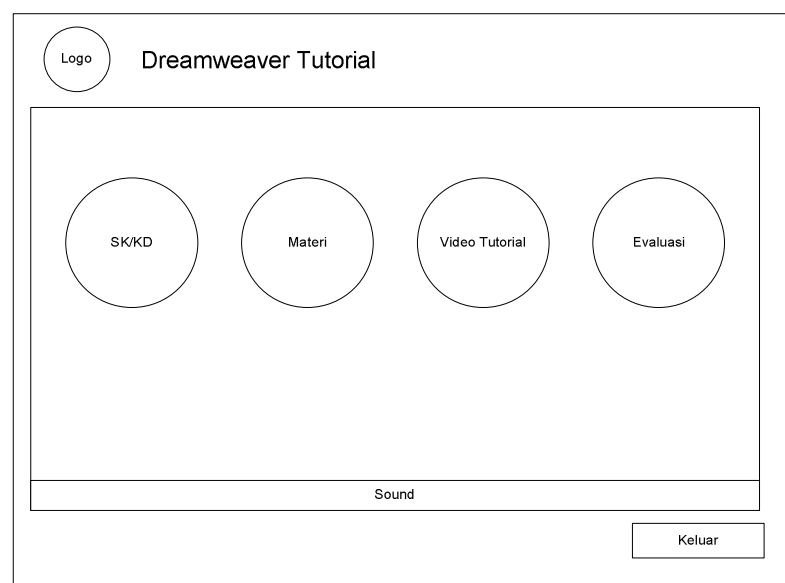

Gambar 4.2 Rancangan Antarmuka Form Utama

\subsubsection{Uji Coba Program}

Media pembelajaran dreamweaver model tutorial pada mata pelajaran pelajaran mengelola isi halaman web telah diuji coba berdasarkan kasus yang ada. Berikut contoh tampilan program.

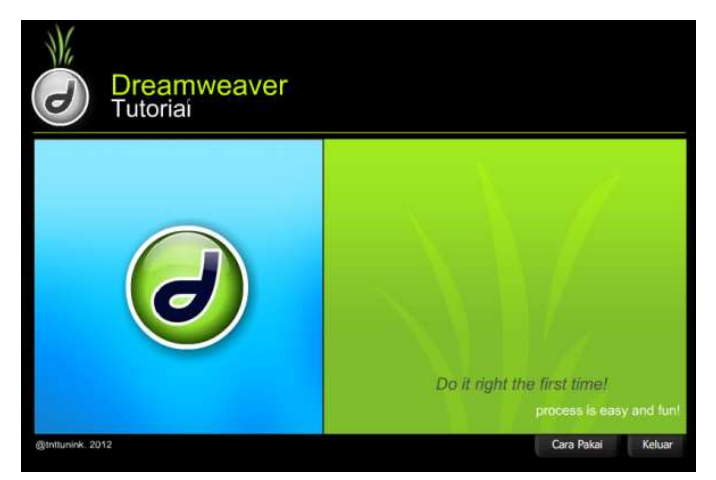

Gambar 4.3 Menu masuk media

\subsubsection{Kategori Respon Siswa}

Kategori respon siswa terhadap pengembangan media pembelajaran dreamweaver model tutorial dikumpulkan dengan menggunakan angket respon siswa.berikut hasil dari respon siswa. 


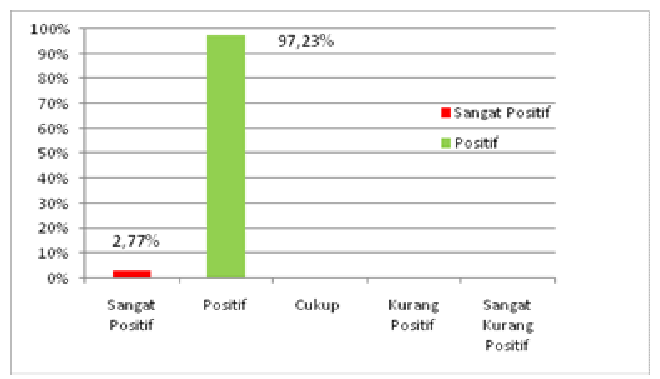

Gambar 4.4 Grafik Respon Siswa

Respon siswa multimedia di SMK Negeri 3 Singaraja terhadap pengembangan media pembelajaran dreamweaver model tutorial tersebar pada kategori sangat positif $2,85 \%$, positif $97,15 \%$, cukup positif $0 \%$, kurang positif $0 \%$ dan sangat kurang positif $0 \%$. Rata-rata skor respon siswa yaitu 61 sehingga respon siswa terhadap pengembangan media pembelajaran dreamweaver model tutorial dapat dikategorikan positif.

\subsubsection{Respon Guru}

Respon guru terhadap pengembangan media pembelajaran dreamweaver model tutorial dikumpulkan dengan menggunakan angket respon guru.

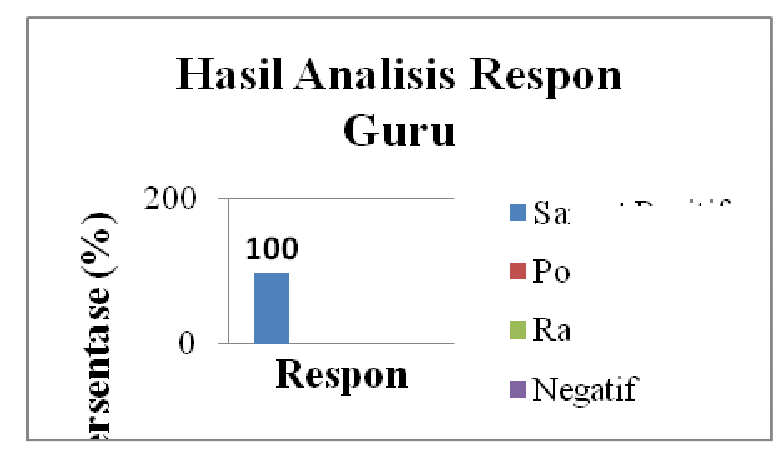

Gambar 4.5 Grafik Respon Siswa

Respon guru terhadap pengembangan media pembelajaran dreamweaver model tutorial tersebar pada kategori sangat positif $100 \%$, positif $0 \%$, ragu-ragu $0 \%$, negatif $0 \%$ dan sangat negatif $0 \%$. Rata-rata skor respon guru yaitu 73 .

\subsection{PEMBAHASAN}

Berdasarkan analisis sumber belajar yang dilakukan penulis, sangat diperlukan pengembangan media pembelajaran dreamweaver model tutorial pada mata pelajaran mengelola isi halaman web untuk siswa kelas XI program keahlian multimedia di SMK Negeri 3 Singaraja. Karena penggunaan media pembelajaran model tutorial dalam proses belajar mengajar dapat meningkatkan efisiensi, meningkatkan motivasi, memfasilitasi belajar aktif, memfasilitasi belajar 
eksperimental, konsisten dengan belajar yang berpusat pada siswa dan memandu untuk belajar lebih baik. Pengembangan media pembelajaran dreamweaver model tutorial untuk mata pelajaran mengelola isi halaman web ini selain mampu meningkatkan keterampilan siswa dalam membuat halaman web juga mampu mengoptimalkan hasil belajar. Hal ini disebabkan karena pada media model tutorial ini selain berisi materi dan video tutorial juga disertai dengan soal latihan sehingga bisa mengukur kemampuan masing-masing siswa.

Media pembelajaran model tutorial ini sudah mengalami beberapa perbaikan. Perbaikan yang dilakukan yaitu dari para ahli, para ahli yang dilibatkan yaitu ahli isi, ahli media, ahli desain, dan guru mata pelajaran mengelola isi halaman web. Ini dilakukan untuk menyempurnakan isi media pembelajaran sehingga siap diujikan di lapangan. Disamping itu juga untuk mempermudah siswa dalam mengikuti dan mempraktekan langkah demi langkah video tutorial yang ada pada media pembelajaran model tutorial. Dengan media pembelajaran model tutorial tersebut siswa menjadi lebih mandiri dalam membuat dan mempraktekan pembuatan halaman web sesuai dengan tutorial disamping itu guru menjadi lebih mudah dalam menjelaskan materi kepada siswa.

Dari persentase respon siswa terhadap pengembangan media pembelajaran model tutorial pada mata mengelola isi halaman web dapat dikategorikan positif. Respon positif tersebut menunjukkan bahwa siswa senang dan termotivasi dalam belajar dengan menggunakan media pembelajaran model tutorial. Hal ini disebabkan karena media pembelajaran model tutorial ini berisi video tutorial yang bisa di praktekan langsung, evaluasi bisa digunakan untuk mengukur kemampuan siswa, dan dapat menambah wawasan pengetahuan serta menambah kemandirian mereka dalam belajar.

\section{PENUTUP}

\subsection{SIMPULAN}

Berdasarkan hasil analisis data dan pembahasan pada penelitian ini, maka dapat diambil simpulan sebagai berikut.

1. Pengembangan media pembelajaran dreamweaver model tutorial pada mata pelajaran mengelola isi halaman web untuk siswa kelas XI program keahlian multimedia di SMK Negeri 3 Singaraja dikembangkan dengan menggunakan Macromedia Flash 8, serta beberapa software pendukung seperti Photoshop untuk membuat dan mengedit gambar, Cool Edit Pro 2 untuk pengolahan suara, dan Adobe Premiere Pro1.5, Adobe Dreamweaver Cs3, Macromedia Dreamweaver, Xampp, dan Camtasia Studio 7 untuk mengedit video. Media pembelajaran dreamweaver model tutorial ini memungkinkan siswa untuk belajar mandiri dan mempraktekan langsung tahap demi tahap pembuatan halaman web yang diinginkan sesuai dengan media.

2. Respon siswa dan guru terhadap pengembangan media pembelajaran dreamweaver model tutorial pada mata pelajaran mengelola isi halaman web, yaitu siswa dengan kategori sangat positif $2,77 \%$, siswa dengan kategori 
positif $97,23 \%$ dan guru dengan kategori sangat positif $100 \%$. Sehingga media pembelajaran dreamweaver model tutorial ini layak diujikan secara ekperimen.

\subsection{SARAN}

Saran-saran yang disampaikan berkenaan dengan pengembangan media pembelajaran dreamweaver model tutorial pada mata pelajaran mengelola isi halaman web ini yaitu.

1. Media pembelajaran dreamweaver model tutorial pada mata pelajaran mengelola isi halaman web yang berupa CD Interaktif dikembangkan berdasarkan karakteristik siswa di SMK N 3 Singaraja kelas XI, sehingga bila digunakan pada siswa di SMK yang lain, pada kelas yang lain atau bila ditemukan kesalahan atau kelemahan yang perlu diperbaiki, maka produk pengembangan ini dipersilakan untuk direvisi seperlunya.

2. Pengembangan media pembelajaran dreamweaver model tutorial pada mata pelajaran mengelola isi halaman web ini tidak dimaksudkan untuk mengatasi seluruh permasalahan dalam mata pelajaran mengelola isi halaman web khususnya kelas XI SMK N 3 Singaraja. Maka dari itu diharapkan kepada guru yang menggunakan media pembelajaran model tutorial ini dapat menggunakan sumber lain sebagai penunjang dalam proses pembelajaran.

3. Produk media pembelajaran sebaiknya dikembangkan lebih lanjut pada mata pelajaran lain, guna meningkatkan daya tarik dan cara pandang siswa terhadap pelajaran yang sulit dan kurang menarik .

4. Bagi peneliti yang ingin mengembangkan media pembelajaran dreamweaver model tutorial, agar menambahkan latihan soal pada setiap materi dan menerapkan penelitian eksperimen, guna mengetahui peningkatan perkembangan siswa dari penggunaan media pembelajaran dreamweaver model tutorial

5. Kepada setiap pihak yang ingin membuat media dengan menggabungkan teknik video shooting agar memperkaya referensi, karena penggunaan konsep video shooting pada media pembelajaran model tutorial ini, merupakan tahap awal bagi pengembang menuju industri pertelevisian.

\section{DAFTAR PUSTAKA}

Ardhana, I W. 2002. "Konsep Penelitian Pengembangan dalam Bidang Pendidikan dan Pembelajaran". Makalah disampaikan pada Lokakarya Nasional Angkatan II Metodologi Penelitian Pengembangan Bidang Pendidikan dan Pembelajaran. Malang, Universitas Negeri Malang.

Bovee, Courland. 1997. Business Communication Today. New York. Prentice Hall. 
Candiasa, I Made. 2010. Statistik Univariat dan Bivariat Disertai Aplikasi SPSS. Singaraja: Unit Penerbit Universitas Pendidikan Ganesha.

Hamalik. 2005. Perencanaan Pengajaran Berdasarkan Pendekatan Sistem. Jakarta: Bumi Aksara.

Haryoko, Sapto. 2009. "Efektivitas Pemanfaatan Media Audio-Visual Sebagai Alternatif Optimalisasi Model Pembelajaran". http://journal.uny.ac.id/index.php/jee/article/viewFile/347/249 (diakses tanggal 12 januari 2012 ).

Hermawan, A H, dkk. (2004). Pengembangan Model Pembelajaran Berbasis Komputer (Teori dan Praktek). Bandung: Jurusan Kurikulum dan Teknologi Pendidikan Fakultas Ilmu Pendidikan Universitas Pendidikan Indonesia.

Laurahasiel. 2009. "Multimedia Dalam Pembelajaran". http://laurahasiel.wordpress.com/2009/06/19/Multimedia-DalamPembelajaran/ (diakses tanggal 10 Juli 2009).

Noor Fajar, Rahmawati. 2010. Pembangunan Sistem Informasi Perpustakaan Pada Badan Koordinasi Survei Dan Pemetaan Nasional (Bakosurtanal) Berbasis Web. Tugas Akhir (Tidak diterbitkan) Program Keahlian Manajemen Informatika, Direktorat Program Diploma, Institut Pertanian Bogor.

Santyasa, I W. 2007. "Landasan Konseptual Media Pembelajaran". Makalah disajikan dalam Workshop Media Pembelajaran bagi Guru-Guru SMA Negeri Banjar Angkan, Undiksha, Klungkung 10 Januari 2007.

Soenarto. 2005. "Metodologi Penelitian Pengembangan untuk Peningkatan Kualitas Pembelajaran (research Methodology to The Improvent Of Instruction)". Makalah disajikan dalam_Pelatihan Nasional Penelitian Peningkatan Kualitas Pembelajaran dan Penelitian Tindakan Kelas (PPKP dan PTK) Bagi Dosen LPTK, Denpasar: Agustus.

Sugiyono. 2008. "Metode Penelitian Pendidikan Pendekatan Kuantitatif, Kualitatif dan R \& D". Bandung: Alfabeta CV.

Udayana. 2010. Pengembangan Media Pembelajaran Multimedia Model Tutorial Pada Mata Pelajaran Animasi 3 Dimensi. Skripsi (tidak diterbitkan). Jurusan Pendidikan Teknologi Informasi, UNDIKSHA. 